
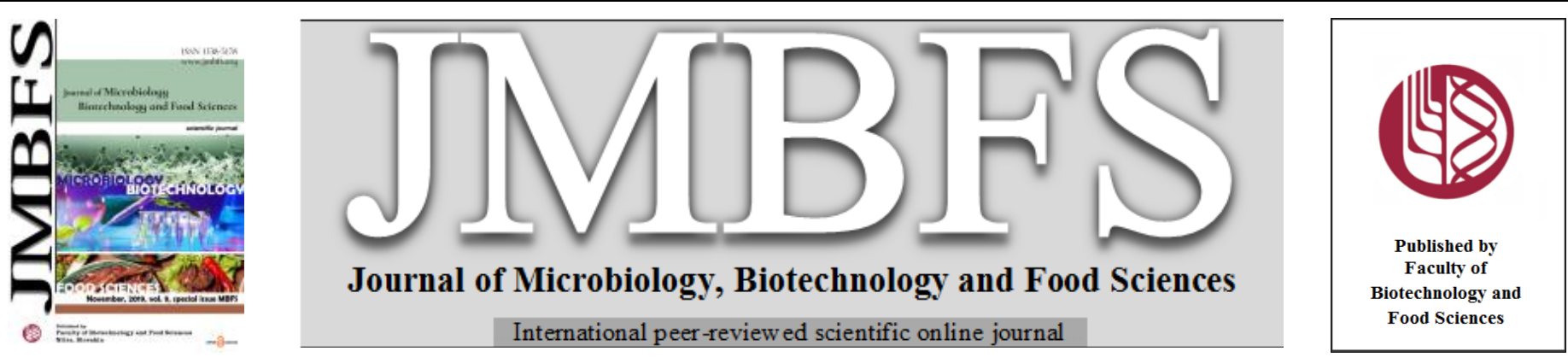

\title{
COMPARISON OF MEAT OXIDATIVE STABILITY FREE-REARING AND FARM-REARING PHEASANTS
}

\section{Jana Tkáčovál, Peter Šmehýl ${ }^{2}$, Adriana Pavelkovál, Marek Bobko ${ }^{1}$, Juraj Čuboñ ${ }^{1}$, Peter Haščik ${ }^{1}$, Mária Angelovičová3 , Miroslav Kročko ${ }^{1}$, Martina Gondeková ${ }^{4}$}

Address(es): Ing. Jana Tkáčová, PhD.

${ }^{1}$ Slovak University of Agriculture, Faculty of Biotechnology and Food Sciences, Department of Evaluation and Processing of Animal Products, 949 76, Nitra, Tr. A. Hlinku 2, Slovakia.

${ }^{2}$ Slovak University of Agriculture, Faculty of Agrobiology and food resources, Department of poultry science and small animal husbandry, 94976 Nitra, Nitra, Tr. A. Hlinku 2, Slovakia.

${ }^{3}$ Slovak University of Agriculture, Faculty of Biotechnology and Food Sciences, Department of Food Hygiene and Safety, 949 76, Nitra, Tr. A. Hlinku 2, Slovakia.

${ }^{4}$ Animal Production Research Centre, Nitra, Department of Animal Breeding and Product Quality, Hlohovecká 2, 95141 Lužianky, Slovakia.

*Corresponding author: jana.tkacova@uniag.sk

doi: 10.15414/jmbfs.2019.9.special.453-456

\section{ARTICLE INFO}

Received 30. 7. 2019

Revised 13. 9. 2019

Accepted 16. 10. 2019

Published 8. 11. 2019

Regular article OPEN $\partial_{\text {ACCESS }}$

\begin{abstract}
The aim of this work was to compare contents of fat and oxidative stability of farm-rearing and free-rearing common pheasant (Phasianus colchicus). For experiment were used pheasants from two types of breeding. The first group came from free-rearing and it was fed by a natural way and in the winter months were fed with wheat, maize and barley. For the experiment analysis were used from free and farm-rearing 10 male of pheasants and 10 female of pheasants. The second group was created by pheasants, which came from farm breeding from VPP Kolíñany farm, Žirany resort. The group of farm-rearing pheasants was reared in farm conditions until the time of hunt (70 days). The pheasants were fed by special feed mixtures (BŽ1, BŽ2, BŽ3) intendent for fattening of pheasants. All pheasants were caught on common hunting in Nitra area. The first meat analyzes were carried out 1 day after the pheasants hunting. Other samples were analyzed after 6 months of freezing storage. The different contents of fat in breast muscle was significant $(\mathrm{P} \leq 0.05)$ between groups farm-rearing and free-rearing and contents of fat was significant $(\mathrm{P} \leq 0.05)$ between male and female into group too. The contents of malondialdehyde (MDA) in breast muscle was in range from 0.025 to $0.056 \mathrm{mg} \cdot \mathrm{kg}^{-1}$ at the start of storage $\left(1^{\text {st }}\right.$ day) and at the end of storage ( $6^{\text {th }}$ month) was in range from 0.113 to $0.197 \mathrm{mg} \cdot \mathrm{kg}^{-1}$. The significant differences $(\mathrm{P} \leq 0.05)$ in contents of MDA were between male and female from farm-rearing in sixth month of storage. The significant differences $(\mathrm{P} \leq 0.05)$ in contents of MDA were between group farm-rearing and free-rearing at the beginning and at ending of storage.
\end{abstract}

Keywords: oxidative stability, malondialdehyde, pheasant, free-rearing, farm-rearing

\section{INTRODUCTION}

Meat from wild-living game is a highly valued food (Paulsen et al., 2008; ElGhareeb et al., 2009; Hofbauer et al., 2010). Currently, the common pheasant is the most abundant, widespread and economically important non-migratory game bird in Europe (CABS, 2010; Quaresma et al., 2016). In the past, animals were mostly associated with hunting, but nowadays, a freely available commodity is increasing in popularity (Standarová et al., 2012; Hrabčáková et al., 2013a). Currently, it is possible to see an increasing trend in consumption of feathered game in Slovakia. Although wild-living game currently represents only a tiny fraction of the total meat consumption. Its dietary value is very high and corresponds to the demands of modern man for nutrition (Hell et al., 2008). For the last years, poultry breeding became the most extensively developing branch of animal husbandry (Genchev et al., 2008). Common Pheasant (Phasianus colchicus) is bred on farms for hunting purposes in many countries (Torres $\boldsymbol{e t}$ al. 1995; Canning, 2005; Gonzáles-Redondo and García-Domínguez, 2012; Hrabčáková et al., 2013b).

Consumers favor meat that is authentic, tasty, rich in protein and low in lipid (Franco and Lorenzo, 2013).

Similarly to other white meats, pheasant meat has high protein and low fat contents, an interesting proportion of essential and unsaturated fatty acids, and high content of certain B-group vitamins (Večerek et al., 2005; Quaresma et al., 2016). Due to its specific composition (low fat content, high protein content, favorable ratio of essential and unsaturated fatty acids) is this commodity frequently sought by consumers (Standarová et al., 2012; Hutařová and Večerek, 2013)

Meat from wild-living game with its low fat contents belongs to a group of meats very rich in protein. These proteins have an extraordinary biological value and are known to be highly used in the construction of human body proteins
(Vodňanský et al., 2009). Pheasant meat is characterized by high nutritive value, as evidenced by high protein contents of breast (23.5-25.2\%) and leg muscles (19.4-22.7\%), and low proportion of fat (0.6-1.1\%), especially in breast muscles (Večerek et al., 2005; Kuźniacka et al., 2007; Gašparovič et al., 2017) and 2.0$5.1 \%$ in leg muscles (Večerek $\boldsymbol{e t}$ al., 2005). In terms of fat, the meat of the pheasant contains the highest proportion of unsaturated fatty acids -70.67 g.100 $\mathrm{g}^{-1}$ of total fatty acids (Vodňanský et al., 2009).

The contents of most amino acids in breast and thigh muscles (in relation to dry matter) is higher in pheasants than in broiler chickens (Straková et al., 2006; Gasparovic et al., 2017) in addition, vitamins contain higher amounts of pantothenic acid, vitamin B6, riboflavin and thiamine. Low fat contents also results in low cholesterol contents (Vodňanský et al., 2009). Due to its low fat contents, the energy content of the wild-living game is considerably low (Čuboň et al., 2012).

A number of authors, Tucak et al. (2004), dealt with comparing the quality pheasant meats of farmed and wild breeding farm pheasant meats while poultry needs to be fed concentrated, easily digestible forms of feeds that supply not only adequate amounts, but also a good balance of nutrients (Ravindran, 2014).

Lipid oxidation, called "autoxidation," is the result of radical chain reactions that occur in three simultaneous phases (initiation, propagation and completion). The resulting products depend on the substrates, which are generally unsaturated fatty acids (Guyon et al., 2016). The beginning of oxidation is influenced by temperature, light or metal ions (Angelovič et al., 2015). The two first phases lead to the formation of radicals, which are rapidly transformed into non-radical compounds such as conjugated dienesand hydroperoxides, which are both considered primary products of lipid oxidation. These compounds decompose further and give rise to carbonyl compounds, ketones, alcohols, and aldehydes, which are considered secondary products of lipid oxidation (Guyon et al., 2016). 
Malondialdehyde (MDA) is a relatively stable secondary product of the oxidative degradation of polyunsaturated fatty acids (PUFAs). It is a three-carbon dialdehyde that can exist in various forms depending on the $\mathrm{pH}$ value. Cyclic peroxides, biclyclic endoperoxides, and hydroperoxyl are some of its major precursors (Lima et al., 2013; Amaral et al., 2018). MDA is important for peroxidation through the TBARS test (Thiobarbituric Acid Reactive Substances), the most widely used assay to assess the effects of lipid oxidation on meat and meat products (Min and Ahn, 2005; Amaral et al., 2018).

Another important secondary oxidation products are the volatile compounds responsible for the off-odor and off-flavor such as propanal, hexanal and pentanal (Barriuso et al., 2013; Lorenzo et al., 2013; Guyon et al., 2016; Cunha et al., 2018). industry and scientific research since it can be used to determine lipid

\section{MATERIAL AND METHODS}

For the experiment was used common pheasant Phasianus colchicus - commonly hunted feathered game bird in Slovakia. For the purpose of the experiment, pheasants were used from two types of breeding. The first group was imagined by pheasants that were from free-rearing. Individuals obtained food in a natura way and were fed in the winter months with wheat, maize and barley. For the experiment analysis were used 10 male pheasants and 10 female pheasants from free-rearing and from farm rearing.

The second group was created by pheasants, which came from farm breeding from VPP Kolíňany farm, Žirany resort. The pheasants were fed by special feed mixtures for fattening pheasants.

The feed mixture BŽ1 was used from 1 to 21 days, BŽ2 was used from 22 to 42 days and BŽ3 was used from 43 to 70 days of feeding period. Young pheasants aged from 8 to 10 weeks were removed to outdoor aviaries and hold there until the day of hunt. The compositions of basal diets are shown in Table 1. The group of farmed pheasants was reared in farm conditions until the time of hunt.

Table 1 Composition of feed mixtures

\begin{tabular}{|c|c|c|c|}
\hline Ingredients (\%) & $\begin{array}{l}\text { Starter }(B Z ̌ 1) \\
\left(1^{\text {st }}-21^{\text {st }} \text { day of age }\right)\end{array}$ & $\begin{array}{l}\text { Grower (BŽ2) } \\
\left(22^{\text {nd }}-42^{\text {th }} \text { day of age }\right)\end{array}$ & $\begin{array}{l}\text { Finisher }(\mathrm{BŽ} 1) \\
\left(43^{\text {nd }}-70^{\text {st }} \text { day of age }\right)\end{array}$ \\
\hline Wheat bran & 5 & - & - \\
\hline Fish meal $(71 \% \mathrm{~N})$ & 4 & 5 & 5 \\
\hline Dried blood & 5 & 5 & 5 \\
\hline Dried yeast & 2 & 2.5 & 5 \\
\hline Soybean meal $(4 \% \mathrm{~N})$ & 14 & 31.3 & 18 \\
\hline Extracted groundnut & - & 10 & 10 \\
\hline Maize & 33 & 26.5 & 36.7 \\
\hline Wheat & 7 & 10 & 10 \\
\hline Barley & 25 & - & - \\
\hline Shelled oats & - & 5 & 5 \\
\hline Dried vitamins & 5 & 3 & 3 \\
\hline Fodder salt & - & 0.2 & 0.3 \\
\hline Monocalcium phosphate & - & 0.5 & 1 \\
\hline Dicalcium phosphate & - & 1 & 1 \\
\hline \multicolumn{4}{|l|}{ Nutrient composition (g. $\left.\mathrm{kg}^{-1}\right)$} \\
\hline NL & $\min 260.0$ & $\min 240.0$ & $\min 130.0$ \\
\hline ME (MJ.kg $\left.{ }^{-1}\right)$ & $\min 11.5$ & $\min 11.5$ & $\min 11.5$ \\
\hline Ash & $\max 80.0$ & $\max 80.0$ & $\max 80.0$ \\
\hline Fiber & $\max 60.0$ & $\max 60.0$ & $\max 60.0$ \\
\hline Lysine & $\min 16.0$ & $\min 10.0$ & $\min 4.0$ \\
\hline Methionine and cysteine & $\min 9.0$ & $\min 4.0$ & $\min 4.0$ \\
\hline of this methionine & $\min 5.0$ & $\min 3.0$ & $\min 3.0$ \\
\hline $\mathbf{C a}$ & $\min 11.0$ & $\min 11.0$ & $\min 11.0$ \\
\hline $\mathbf{P}$ & $\min 7.0$ & $\min 7.0$ & $\min 6.0$ \\
\hline $\mathbf{N a}$ & $1.5-4.5$ & $1.5-4.5$ & $1.5-4.5$ \\
\hline Mn (mg.kg $\left.{ }^{-1}\right)$ & $\min 95.0$ & $\min 95.0$ & $\min 95.0$ \\
\hline Fe $\left(\mathrm{mg} . \mathrm{kg}^{-1}\right)$ & $\min 60.0$ & $\min 60.0$ & $\min 60.0$ \\
\hline $\mathrm{Cu}\left(\mathrm{mg} . \mathrm{kg}^{-1}\right)$ & $\min 6.0$ & $\min 6.0$ & $\min 6.0$ \\
\hline Zn (mg.kg $\left.{ }^{-1}\right)$ & $\min 90.0$ & $\min 90.0$ & $\min 90.0$ \\
\hline Vitamin A (mj.kg-1) & $\min 10000$ & $\min 10000$ & $\min 10000$ \\
\hline Vitamin $D_{3}\left(\mathbf{m j} . \mathrm{kg}^{-1}\right)$ & $\min 2000$ & $\min 1500$ & $\min 1500$ \\
\hline$\underset{\left(\mathrm{mg.kg}^{-1}\right)}{\text { Vitamin }} \mathbf{E}-\alpha$-tocoferol & $\min 20.0$ & $\min 20.0$ & $\min 20.0$ \\
\hline Vitamin $B_{2}\left(\mathrm{mg} \mathrm{kg}^{-1}\right)$ & $\min 8.0$ & $\min 6.0$ & $\min 6.0$ \\
\hline $\operatorname{Vitamin} B_{12}\left(\mu . k^{-1}\right)$ & $\min 30.0$ & $\min 20.0$ & $\min 20.0$ \\
\hline
\end{tabular}

All pheasants were caught on common hunting in the hunting area of M VI Nitra in accordance with the Hunting Act of Slovak Republic no. 274/2009 Coll. and 72/2012 Coll. individuals were hunting during the month of December 2017. The hunters respected the Regulation (EC) No 853/2004 and No 854/2004 during the hunting. There was a natural cooling of the pheasants. After hunting, the animals were stored for 24 hours in a refrigeration apparatus at $4{ }^{\circ} \mathrm{C}$. Subsequently, the skin with the feathers was removed and samples of breast muscle were taken to perform the oxidative stability analysis. The first analysis was performed after 1 day of hunting. Other samples were stored 6 months at the temperature $-18{ }^{\circ} \mathrm{C}$ after first analysis and after this period were carried out analysis.

\section{Determination of fat contents}

The basic chemical composition analyses including the fat content was carried out by FoodScan LAB Analyzer (FOSS, Denmark). The homogenized sample of meat - musculus pectoralis major was analysed by NIR (Near infrared technology, USA) technology with monochromator working with $850-1050 \mathrm{~nm}$ wavelengths. The fat content was calculated as $\mathrm{g} .100 \mathrm{~g}^{-1}$ in wet musculus pectoralis major.

\section{Determination of MDA contents}

The content of MDA was determined according Marcinčák et al. (2004). For analysis we used UV VIS spectrophotometer Jenway 7305 (United Kingdom JENWAY). The samples and standards were measured at a wavelength $532 \mathrm{~nm}$ After constructing the calibration curve was calculated results will as the mg of MDA in $1 \mathrm{~kg}$ of sample.

\section{Statistical analysis}

Obtained results were carried out according to Statistic Analysis System SAS software with the Enterprise Guide 4.2 application (version 9.3, SAS Institute Inc., USA, 2008). We used the nonparametric Wilcoxon's t-test for comparison of two independent sets of data.

\section{RESULTS AND DISCUSSION}

The results of breast muscle fat contents of farm-rearing and free-rearing are shown in Table 2. Based on the obtained results, we found higher fat contents in farm-rearing pheasants (1.73 g.100 g $\mathrm{g}^{-1}$ - male, $2.23 \mathrm{~g} .100 \mathrm{~g}^{-1}$ - female) than in free-rearing pheasants (1.43 g.100 g $\mathrm{g}^{-1}$ male $1.62 \mathrm{~g} .100 \mathrm{~g}^{-1}$ female). From the statistical aspect we have found statistical differences $(\mathrm{P} \leq 0.05)$ between sex in farm-rearing as well as free-rearing pheasant, and also a comparison $(\mathrm{P} \leq 0.05)$ of 
pheasant female and male between monitored rearing. The fat content found in pheasant breast by Slamečka et al. (2003) was $1.17 \mathrm{~g} .100 \mathrm{~g}^{-1}$. Kováčiková $\boldsymbol{e t}$ al. (2001) report higher results etc. $3.33 \mathrm{~g} .100 \mathrm{~g}^{-1}$ of fat contents in pheasant breast muscle, on the contrary, Tucak et al. (2008) who report that a fat contents in the breast muscle was only $0.6 \mathrm{~g} .100 \mathrm{~g} \mathrm{~g}^{-1}$ and Golze (2010) $1.0 \mathrm{~g} .100 \mathrm{~g} \mathrm{~g}^{-1}$. Vitula et al. (2011) report fat contents in pheasant farm-rearing 1.86 g. $100 \mathrm{~g}^{-1}$ resp. $4.66 \mathrm{~g} .100$ $\mathrm{g}^{-1}$ fat in dry matter. Večerek $\boldsymbol{e t}$ al. (2005) report fat contents of breast muscle in 70 days of age pheasants $2.38 \mathrm{~g} .100 \mathrm{~g} \mathrm{~g}^{-1}$ in farm-rearing. Fat content monitored by Haščík et al. (2010) were $1.27 \mathrm{~g} .100 \mathrm{~g}^{-1}$ in female and $1.06 \mathrm{~g} .100 \mathrm{~g}^{-1}$ in male pheasants from farm-rearing.

Table 2 The comparison of fat contents $\left(\mathrm{g} .100 \mathrm{~g}^{-1}\right)$ in musculus pectoralis major in farm-rearing and free-rearing pheasants

\begin{tabular}{llllll}
\hline Group & Sex & means & SD & SE & P-value \\
\hline Farm rearing & Male & $1.73^{\mathrm{aB}}$ & 1.17 & 0.053 & $<0.0001$ \\
& Female & $2.23^{\mathrm{bB}}$ & 0.409 & 0.129 & $<0.0001$ \\
\hline Free-rearing & Male & $1.43^{\mathrm{aA}}$ & 0.086 & 0.027 & 0.054 \\
& Female & $1.62^{\mathrm{bA}}$ & 0.170 & Farm Female : Free Female 0.0010
\end{tabular}

$\mathrm{P} \leq 0,05$

Farm Female : Free Female 0.0010

Legend: Data are reported as mean - arithmetic average, SD - standard deviation, SE - standard error, a,b means with different superscripts in the same column are significantly different $(\mathrm{P} \leq 0.05)$ between one type of rearing; A,B means with different superscripts in the same column are significantly different $(\mathrm{P} \leq 0.05)$ between male or female

The TBARS test (contents of MDA) is an available indicator of meat lipid peroxidation (Gamal et al., 2003; Hussein and Selim, 2018). In our experiment, we compared the MDA contents in the musculus pectoralis major pectoral muscle at the beginning of storage and after the 6 months of storage. The concentration of malondialdehyde $\left(\mathrm{mg} \cdot \mathrm{kg}^{-1}\right)$ in meat of pheasant at the start of storage is shown in Table $3 . \quad$ At the beginning of storage, the lowest

concentrations of MDA were found in female pheasants from free-rearing $(0.025$ $\left.\mathrm{mg} \cdot \mathrm{kg}^{-1} \mathrm{MDA}\right)$. Approximately the same values were recorded between male and female from free-rearing. There were also no significant differences $(\mathrm{P} \geq 0.05)$ between groups at the beginning of storage.

Table 3 The comparison of malondialdehyde concentration $\left(\mathrm{mg} \cdot \mathrm{kg}^{-1}\right)$ in musculus pectoralis major of pheasant at the start $\left(1^{\text {st }}\right.$ day) of storage

\begin{tabular}{llllll}
\hline Group & Sex & Mean & SD & SE & P-value \\
\hline Farm rearing & Male & 0.049 & 0.015 & 0.003 & NS \\
\hline \multirow{2}{*}{ Free-rearing } & Female & 0.056 & 0.016 & 0.003 & \\
& Male & 0.037 & 0.035 & 0.008 & NS \\
\hline
\end{tabular}

Legend: Data are reported as mean - arithmetic average, SD - standard deviation, SE - standard error, NS - non significant differences (P $\geq 0.05)$

At the beginning of storage were recorded the highest values of MDA in male (0.049 mg.kg-1) and female $0.056 \mathrm{mg} \cdot \mathrm{kg}^{-1}$ from farm-rearing, which also corresponds to higher fat contents in breast muscle of farm pheasants between male and female for farm-rearing and free-rearing pheasants.

During the storage period (Table 3,4), the contents of MDA in female pheasant breast muscle increased in farm-rearing from 0.056 to $0.197 \mathrm{mg} \cdot \mathrm{kg}^{-1}$ and for male from 0.049 to $0.113 \mathrm{mg} \cdot \mathrm{kg}^{-1}$. We found lower MDA values during storage in free-rearing pheasants (female - from 0.025 to $0.150 \mathrm{mg} \cdot \mathrm{kg}^{-1}$ and in male from 0.037 to $\left.0.137 \mathrm{mg} \cdot \mathrm{kg}^{-1}\right)$.

Table 4 The concentration of malondialdehyde $\left(\mathrm{mg}^{\mathrm{kg}} \mathrm{kg}^{-1}\right)$ in meat of pheasants at the end $\left(6^{\text {st }}\right.$ month) of storage

\begin{tabular}{llllll}
\hline Group & Sex & Mean & SD & SE & P-value \\
\hline Farm rearing & Male & $0.113^{\mathrm{a}}$ & 0.035 & 0.010 & $<0.0001$ \\
\hline \multirow{2}{*}{ Free-rearing } & Female & $0.197^{\mathrm{bA}}$ & 0.048 & 0.013 & \\
& Male & 0.137 & 0.056 & 0.009 & NS \\
\hline & Female & $0.150^{\mathrm{B}}$ & 0.064 & 0.011 & -
\end{tabular}

Legend: Data are reported as mean - arithmetic average, SD - standard deviation, SE - standard error, a,b means with different superscripts in the same column are significantly different $(\mathrm{P} \leq 0.05)$ between one type of rearing; $A, B$ means with different superscripts in the same column are significantly different $(\mathrm{P} \leq 0.05)$ between male or female

Compared to our results Bobko et al. (2015) founded contents of malondialdehyde during storage in chicken breast at $6^{\text {th }}$ month $\left(0.157 \mathrm{mg} \cdot \mathrm{kg}^{-1}\right)$. At the beginning of storage contents of malondialdehyde was $0.106 \mathrm{mg} . \mathrm{kg}^{-1}$. The contents of MDA was also investigated by Marcinčák $\boldsymbol{e t}$ al. (2008), where, however, at the beginning of the study period, the values in breast in chicken were $0.14 \mathrm{mg} \cdot \mathrm{kg}^{-1}$ and after 6 months of storage in freezer 0.184 mg.kg ${ }^{-1}$. Similar values were achieved by Haščík et al. (2011) $0.065 \mathrm{mg} \cdot \mathrm{kg}^{-1}$ contents of MDA in chicken at the start of the experiment and however, at 6 months of storage it was only $0.137 \mathrm{mg} \cdot \mathrm{kg}^{-1}$ in the breasts of broilers, which is consistent with the results of our experiment.

\section{CONCLUSION}

Pheasant meat has a very interesting dietary value. In Slovakia, the consumption of pheasant meat is increasing as from free-rearing or farm-rearing. Because of the lower fat contents in pheasants from free-rearing, we also observed lower contents of MDA against in farm-rearing pheasants. However, compared to chickens, a faster oxidation can be observed in pheasant from free-rearing. This experiment needs to be continued to confirm this trend.

Acknowledgments: This work was supported by the KEGA no. 027SPU-4/2019 and VEGA no. 1/0144/19
There were significant differences $(\mathrm{P} \leq 0.05)$ between sex at the beginning and at the end of storage in contents of MDA in farm-rearing and there were no significant differences $(\mathrm{P} \geq 0.05)$ between sexes in free-rearing pheasants.

We found significant differences $(\mathrm{P} \leq 0.05)$ only in hens by comparing between the same sex of farm-rearing and free-rearing pheasants at the end of storage period in the breast muscle.

\section{REFERENCES}

AMARAL, A B, SILVA, M. V., LANNES, S. C. S. 2018. Lipid oxidation in meat: mechanisms and protective factors - a review. Food Science and Technology, 38, 1, 1-15. http://dx.doi.org/10.1590/fst.32518.

ANGELOVIČ, M., JABLONICKÝ, J., TKÁČ, Z., ANGELOVIČ, M. 2015 OXIDATIVE STABILITY OF FATTY ACID ALKYL ESTERS: A REVIEW. Potravinarstvo, 9, (1), 417-426. https://doi:10.5219/500.

BARRIUSO, B., ASTIASARÁN, I. ANSORENA, D. 2013. A review of analytical methods measuring lipid oxidation status in foods: A challenging task. European Food Research and Technology, 236(1), 115. https://doi.org/10.1007/s00217-012-1866-9.

BOBKO, M., KROČKO, M., HAŠČ́́K, P., BOBKOVÁ, A. 2015. Oxidative stability of chicken meat after propolis extract application in their diets. Potravinárstvo, 9, 1, 48-52. https://doi.org/10.5219/427.

CANNING, P. 2005. The UK Game Bird Industry - A short study. Ed. Adas. Lincoln, England, pp. 24.

CABS, 2010. Shooting Bag Figures for Waterfowl and Coots, Cranes and Rails. Committee Against Bird Slaughter.

ČUBOŇ, J., HAŠČÍIK, P., KAČÁNIOVÁ, M. 2012. Hodnotenie surovín a potravín živočišneho pôvodu. 1 Nitra: SPU, XXX p. ISBN 978-80-552-0870-1.

CUNHAA, L. C.M., MONTEIRO, M. L. G., LORENZO, J. M., MUNEKATA, P. E.S., MUCHENJE, V., CARVALHO, F. A. L., CONTE-JUNIOR, C. A. 2018. 
Natural antioxidants in processing and storage stability of sheep and goat meat products. Food Research International,111, 379-390. https://doi.org/10.1016/j.foodres.2018.05.041.

EL-GHAREEB, W., R., SMULDERS, F., J., M., MORSHDY, A.,M., A., WINKELMAYER, R., PAULSEN, P. 2009. Microbiological condition and shelf life of meat from hunted game birds. Eur $J$ Wildl Res, 55, 317-323. https://doi:10.1007/s10344-009-0249-4.

FRANCO, D., AND LORENZO, J., M. 2013. Meat quality and nutritional composition of pheasants (Phasianus colchicus) reared in an extensive system. British Poultry Science, 54(5), 594-602 https://doi.org./10.1080/00071668.2013.828195.

GAMAL EL-DIN, A.M., MOSTAFA, A.M., AL-SHABANAH, O.A. ALBEKAIRI, A.M., NAGI, M.N. 2003. Protective effect of Arabic gum against acetaminophen-induced hepatotoxicity in mice. Pharmacol. Res., 48, 631-635. https://doi.org/10.1016/s1043-6618(03)00226-3.

GAŠPAROVIČ, M.,HRNČÁR, C.,GÁLIK, B. 2017. The effect of feed additives in pheasants fattening: A review. Journal of Central European Agriculture, 18(4), 749-761. https://doi.org/10.5513/jcea01/18.4.1953.

GENCHEV, A., MIHAYLOVA, G., RIBARSKI, S., PAVLOV, A. KABAKCHIEV. M. 2008. Meat quality and composition in Japanese quails Trakia Journal of Sciences, 6(4), 72-82. http://www.uni-sz.bg ISSN 1313-3551 (online)

GOLZE, M. 2010. Fasanenproduktion zur Fleischgewinnung und zum Auswildern. Rundschau fur fleischhygiene und Lebensmitteluberwachung, 62, 9-

GONZÁLEZ-REDONDO, P., GARCÍA-DOMÍNGUEZ, P. 2012. Typification and characterisation of the pheasant (Phasianus colchicus) game farms in Spain. Spanish Journal of Agricultural Research, 10, 1005-1015. https://doi.org/10.5424/sjar/2012104-403-11.

GUYON, C., MEYNIER, A., LAMBALLERIE, M. 2016. Protein and lipid oxidation in meat: A review with emphasis on highpressure Treatments. Trends in Food Science \& Technology, 50, 131-143. http://dx.doi.org/10.1016/j.tifs.2016.01.026

HAŠČÍK, P., ELIMAM, I. O. E., BOBKO, M., KAČÁNIOVÁ, M., POCHOP, J. GARLÍK,J., KROČKO, M., ČUBOŇ, J., VAVRIŠINOVÁ, K., ARPÁŠOVÁ, H. CAPCAROVÁ, M., BENCZOVÁ, E. 2011. Regular article oxidative stability of chicken meat after pollen extract application in their diet. Journal of Microbiology, Biotechnology and Food Sciences, 1 (1) 70-82.

HAŠČÍK, P., KULÍŠEK, V., KAČÁNIOVÁ, M., ČUBOŇ, J., VAVRIŠINOVÁ K. 2010. Mäsová úžitkovost' a kvalita mäsa vybraných druhov malej pernatej zveri. Nitra: SPU v Nitre, 187 p. ISBN978-80-552-0349-2

HELL, P., SLAMEČKA, J., VODŇANSKÝ, M. 2008. Produkcia a význam diviny na Slovensku. Myslivost. 12/2008, 54.

HOFBAUER, P., SMULDERS, F. J. M., VODNANSKY, M., PAULSEN, P. EL-GHAREEB, W. R. 2010. A note on meat quality traits of pheasants (Phasianus colchicus). European Journal of Wildlife Research, 56(5), 809-813. https://doi.org/10.1007/s10344-010-0396-7

HRABČÁKOVÁ, P., VOSLÁŘOVÁ, E., BEDÁŇOVÁ, I., PIŠTĚKOVÁ, V., CHLOUPEK, J. 2013 a). Progress of selected biochemical parameters during laying period in pheasant hens housed in enriched cages. Animal Protection and Welfare 2013 (20th International Conference), Brno : VFU, $100-105$ //cit.vfu.cz/welfare/Proceedings2013.pdf

HRABČÁKOVÁ, P., VOSLÁŘOVÁ, E., BEDÁŇOVÁ, I., PIŠTĚKOVÁ, V., CHLOUPEK, J. 2013 b). Selected haematological indices in common pheasant hens housed in enriched cages during laying period. Animal Protection and Welfare 2013 (20th International Conference), Brno : VFU, 106-110 //cit.vfu.cz/welfare/Proceedings2013.pdf

HUNTING ACT 274/2009 Coll. as amended 72/2012 Coll.

HUSSEIN, I. E. AND SELIM, S. 2018. Efficacy of yeast and multi-strain probiotic alone or in combination on growth performance, carcass traits, blood biochemical constituents, and meat quality of broiler chickens. Livestock Science, 216, 153-159. https://doi.org/10.1016/j.livsci.2018.08.008.

HUTAR̆OVÁ, Z. AND VEČEREK, V. 2013. Pheasant hunting from the perspective of animal welfare and meat quality. Animal Protection and Welfare 2013 (20th International Conference), Brno : VFU, 111- 113 //cit.vfu.cz/welfare/Proceedings2013.pdf

KOVÁČIKOVÁ, E., VOJTAŠŠÁKOVÁ, A., PASTOROVÁ, J., SIMONOVÁ, E., HOLČÍKOVÁ, K. 2001. Hydina a zverina- potravinové tabul'ky. ÚVTIP Nitra, 142-147.

KUŹNIACKA, J., ADAMSKI, M., BERNACKI, Z. 2007. Effect of age and sex of pheasants (Phasianus colchicus L.) on selected physical properties and chemical composition of meat. Annals of Animal Science, 7, 45-53.

LORENZO, J. M., GONZÁLEZ-RODRÍGUEZ, R. M., SÁNCHEZ, M., AMADO, I. R., FRANCO, D. 2013. Effects of natural (grape seed and chestnut extract) and synthetic antioxidants (buthylatedhydroxytoluene, BHT) on the physical, chemical, microbiological and sensory characteristics of dry cured sausage "chorizo". Food Research International, 54, 611-620. https://doi.org/10.1016/j.foodres.2013.07.064.

LIMA, D. M., RANGEL, A., URBANO, S., MITZI, G., MORENO, G.M. 2013 Oxidação lipídica da carne ovina. Acta Veterinaria Brasilica, 7(1), 14-28.
MARCINČÁK, S., SOKOL, J., BYSTRICKÝ, P., POPELKA, P., TUREK, P., MÁTÉ, D. 2004. Determination of lipid oxidation level in broiler meat by liquid chromatography. Journal of AOAC International, vol.87, p. 1148-1152. MARCINČÁK, S., CABADAJ, R., POPELKA, P., ŠOLTÝSOVÁ, L. 2008. Antioxidative effect of oregano supplemented to broilers on oxidative stability of poultry meat. Slov Vet Res, 45 (2), 61-66.

MIN, B. and AHN, U. 2005. Mechanism of lipid peroxidation in meat and meat products - a review. Food Science and Biotechnology, 14(1), 152-163.

PAULSEN, P., NAGY, J., POPELKA, P., LEDECKY, V., MARCINCAK, S., PIPOVA, M., SMULDERS, F., J., M., HOFBAUER, P., LAZAR, P. DICAKOVA, Z. 2008. Influence of storage conditions and shotshell wounding on the hygienic condition of hunted, uneviscerated pheasant (Phasianus colchicus). Poult Sci, 87, 191-195. https://doi:10.3382/ps.2007-00039.

QUARESMA, M.A.G., PIMENTEL, F.B., RIBEIRO, A.P., FERREIRA, J.D. ALVES, S.P., ROCHA, I., BESSA, R.J.B., OLIVEIRA, M.B.P.P. 2016. Lipid and protein quality of common pheasant (Phasianus colchicus) reared in semiextensive conditions. Journal of Food Composition and Analysis, 46, 88-95. https://doi.org/10.1016/j.jfca.2015.11.005.

RAVINDRAN, V. 2014. Nutrition of meat animals. Poultry. Editor(s): Michael Dikeman, Carrick Devine, Encyclopedia of Meat Sciences, (Second Edition). Academic Press, 2014, 463-470

ISBN 9780123847348. https://doi.org/10.1016/B978-0-12-384731-7.00024-6. REGULATION (EC) No 853/2004 OF THE EUROPEAN PARLIAMENT AND OF THE COUNCIL of 29 April 2004 laying down specific hygiene rules for food of animal origin.

REGULATION (EC) No 854/2004 OF THE EUROPEAN PARLIAMENT AND OF THE COUNCIL of 29 April 2004 laying down specific rules for the organisation of official controls on products of animal origin intended for human consumption.

SAS(2008) 9.3 Enhanced Logging Facilities, Cary, NC: SAS Institute Inc., 2008. SLAMEČKA, J., VODŇANSKÝ, M., HELL, P. 2008. Produkcia a význam diviny na Slovensku. Myslivost, 12/2008, 54. http://www.myslivost.cz/CasopisMyslivost/Myslivost/2008/Prosinec---2008/PRODUKCIA-A-VYZNAMDIVINY-NA-SLOVENSKU

SLAMEČKA. J., MERTIN, D, HELL, P, MOJTO, J, JURÍČEK, R, 2003. Jatočná výt'ažnost' a kvalita mäsa bažantov z vol'nej prírody a z farmového fovu. Folia venatoria, 33/2003, 135-143

STANDAROVÁ, E., VORLOVÁ, L., GALLAS, L. 2012. The distribution of biogenic amines and polyamines in pheasant meat. Maso International, 2, 63-67 STRAKOVÁ, E., SUCHÝ, P., VITULA, F., VEČEREK, V. 2006. Differences in the amino acid composition of muscles from pheasant and broiler chickens. Archiv für Tierzucht, 49, 508-514. https://doi.org/10.5194/aab-49-508-2006.

TORRES, A., REQUENA, R., GARCÉS, C., CIRIA, J. 1995. La explotación del faisán. Vol. V, Bases de producción animal (Buxadé C, coord), Avicultura clásica y complementaria. Zootecnia. Mundi-Prensa, Madrid, 387- 404.

TUCAK, Z., ŠKRIVANKO, M., KRZNARIĆ, M., POSAVČEVIĆ, Š. BOŠKOVIĆ, I. 2004. Indicators of biological value of the pheasant meat originated from natural and controlled breeding. Acta agriculturae slovenica (12th Int. Symp. “Animal Science Days”), Bled Slovenia, 1, 87-91.

TUCAK, Z., ŠKRIVANKO, M., POSAVČEVIĆ, Š., PERIŠKIĆ, M. BOŠKOVIĆ, I., JUMIĆ, V. 2008. The influence of keeping pheasants in captivity vs. nature on the biological value of meat and its use in human nutrition. Coll Anthropol, 32(3), 959-962.

VEČEREK, V., SUCHÝ , P., STRAKOVÁ, E., 2005. Chemical composition of breast and thigh muscles in fattened pheasant poults. Krmiva, 47 (3), 119-125.

VITULA, F., SUCHÝ, P., STRAKOVÁ, E., KARÁSKOVÁ, K., ZAPLETAL, D., KROUPA, L. 2011. Energy value of meat in selected species of feathered game. Acta Vet., 80, 197-202; https://doi:10.2754/avb201180020197.

VODŇANSKÝ, M., FOREJTEK, P., WINKELMAYER, R., PAULSEN, P., RAJSKÝ, D., MALENA, M., VECEREK, V., LEBERSORGER, P., ZEDKA, H., F. 2009. Hygiena zvěřiny. Brno: Institut ekologie zvěře VFU. XXX p. ISBN 9787305-073-3.

(G. Borgstrom ed.) Part 1, p. 221, Academic Press, New York (G. Borgstrom ed.) Part 1, p. 221, Academic Press, New York (G. Borgstrom ed.) Part 1, p. 221, Academic Press, New York.

SIMAT, V., BOGDANOVIC, T. and BULIC, M. 2011. The effect of different marinating baths on sensory properties and shelf life parameters of cold marinated anchovies (Engraulis encrasicolus, L.). MESO 12, 81-88. LKNUR $\mathrm{UC}, \mathrm{AK}$ an 